\title{
MARKETING INFORMATION ANALYSIS ON EDUCATIONAL SERVICE QUALITY IN TERMS OF INNOVATIVE ACTIVITY
}

\author{
V.I. Nabokov ${ }^{1}$, V.D. Mingalev ${ }^{1}$, A.L. Pustuyev $^{2}$, V.M. Sharapova ${ }^{1}$, O.A. Grytsova ${ }^{3}$, O.D. Rubayeva ${ }^{2}$ I.V. \\ Razorvin $^{4}$
}

${ }^{1}$ Doctor of Economics, Professor, Professor of the Department of Management and Law of the FSBEI HE at the Ural State University of Agriculture, Yekaterinburg, Russia

${ }_{2}$ Doctor of Economics, Professor, Professor of the Department of Management and Economic Theory at FSBEI HE of the Ural SAU, Yekaterinburg, Russia

${ }^{3}$ Head of Economics and Management Department, FSAEI HE Novouralsk Technological Institute, NIAU

"MIPHI", Novouralsk, Russia

${ }^{4}$ Doctor of Economics, Professor, Professor of the Department of Economics and Management of the Ural Institute of Management, RANEPA, Ekaterinburg, Russia

\begin{abstract}
The most important factor of the Russian economy innovative development is the system of education that meets the requirements of modern high-tech production and a new entrepreneurial environment. The fulfillment of these requirements sets the task of high quality of educational services provision for universities. The assessment of training quality is based on the determination of inconsistencies in the educational process carried out by a university and the requirements of employers. The author proposes an author approach to the analysis of marketing information about the quality of educational services, based on the methods of marketing research and GAP-analysis. Market research is the most optimal tool which allows to identify requirements, as well as to assess the degree of the educational service compliance with these requirements. GAP-analysis is used to identify the inconsistencies in the educational process with the requirements of consumers. The result of the study is the development of a system-based method of the questionnaire material structuring to carry out the marketing studies of employers' satisfaction with the quality of university educational services. Also, the methodology was developed to analyze the marketing information received from consumers about educational service quality, which allows us to assess the level of highly qualified personnel training. The results obtained in the process of research can be used by the management of higher education organizations to ensure that the conditions for educational program implementation meet the corresponding requirements of the employers.
\end{abstract}

Keywords: innovative activity, marketing research, educational service quality, GAP-analysis, consumers of educational services, employer

\section{INTRODUCTION}

Universities play a significant role within the conditions of innovative economy. An innovative development involves the introduction of scientific developments in the real sector, the activation of innovation activities of enterprises and business in general. At that, the most important task of the education system is to promote an innovative way of the domestic economy development. On the one hand, universities have a significant scientific and intellectual resource, which contributes to the development of innovation, the implementation of innovation activities; on the other hand, universities train highly qualified personnel necessary for an innovative economy.

The state policy promotes the realization of the task set before the universities. In accordance with the Strategy of Russian Federation Innovative Development for the period up to 2020 [10], the development of human capital is one of the central strategic priorities. Within the framework of this atrategy, they developed and implement the projects aimed at closer interaction of educational organizations and the real sector of the economy and business as a whole. Practically-oriented bachelor's programs, as well as dual-education programs, oriented to personnel training within the conditions of real production taking into account modern professional standards are introduced successfully. 
However, in practice, many universities do not meet the requirements of modern innovative production. Employers note the severance of knowledge obtained by graduates from practice, manifested in the inability to handle modern high-tech equipment, in psychological unpreparedness for the realities of hard workdays, for subordinate management, for behavior norms in the business environment. The way out of this situation seems to us in the attraction of potential employers to the educational process and in a joint development of educational programs.

Many scientists agree that the creation of university-employer connection is reasonable [2-5,8,11-12], since this will allow to solve the problem of expert preparation needed for the economy and to improve the quality of educational services. The purpose of our research was to develop a mechanism for marketing information collection and analysis about the quality of educational services, which allows the planning of educational programs in accordance with the requirements of employers. The following tasks were set in order to achieve this goal:

- to develop a system-based way of the questionnaire material structuring to carry out marketing research on the satisfaction of employers with the quality of university educational services;

- to develop the mechanism analyzing the information received from employers on the quality of educational services, which makes it possible to assess the level of highly qualified personnel training quality.

\section{METHODS OF RESEARCH}

The quality of educational services in modern scientific literature is a university ability to create such conditions for the provision of educational services that will ensure the conformity of the processes and results of an educational organization activity with the requirements of interested parties $[7,9,13-14,16]$. Such interested parties include, among other things, employers, being direct consumers of educational, scientific and innovative activity results of a university. In order to identify the requirements of employers for the educational process, as well as to assess the degree of its compliance with these requirements, it is advisable to conduct marketing research. These studies represent the purposeful process of preparation, gathering and analysis of the marketing information for decision-making directed on requirement satisfaction of some market subjects in respect of qualified personnel, educational, research and other services [6].

The process of marketing research implementation can be represented in general form as follows [1]:

1) definition of research goals, subjects and objects;

2) the choice of methods for marketing research conduct;

3) the development of forms for data collection;

4) the implementation of the research plan - the collection and the analysis of information;

5) the use of research results.

Given this sequence, the marketing research aimed at educational service quality provision is proposed as follows (Figure 1).

\section{STAGE 1. DEVELOPMENT OF MARKETING RESEARCH CONCEPT}

The purpose of marketing research: determination of educational process characteristics, controlled by employers, as well as the evaluation of correspondence extent concerning these characteristics meeting employers' requirements to make decisions for educational service quality provision.

Subjects of marketing research: the subjects interested to improve the quality of educational services - the consumers of services: employers 


\section{STAGE 2. PREPARATION AND DATA COLLECTION}

- The development of questionnaires for employers

- The assessment of employer satisfaction level with the quality of educational services

\section{STAGE 3. RECEIVED INFORMATION ANALYSIS}

- Identification of discrepancies between the requirements of employers and the characteristics of the educational process

- The development of recommendations to eliminate identified non-conformities

\section{STAGE 4. USE OF THE OBTAINED RESULTS DURING DECISION MAKING ABOUT EDUCATIONAL SERVICE QUALITY IMPROVEMENT}

- The adjustment of curricula according to educational programs implemented by a university, taking into account the recommendations to eliminate the existing inconsistencies in the educational process with the consumer requirements.

Figure 1 - The stages of marketing research aimed at educational service quality provision

With the reference to the problem of educational service quality improvement considered in this work, the main purpose of the marketing research is the educational process characteristics determination controlled by employers, the evaluation of these characteristics correspondence degree with their requirements for making justified decisions during educational process planning.

The parties interested in personnel training quality improvement act as the subjects of marketing research, namely, the main consumers of educational organization services, where graduates are employed after graduation.

The object of marketing research is the characteristics that determine the quality of the educational process. Their evaluation is carried out by employers as the result of marketing information provision on the correspondence degree between educational process and its requirements.

There are various methods in order to obtain marketing information from employers, among which the survey is the most common one, and it is necessary to develop a questionnaire that allows you to obtain all necessary information on the correspondence degree between educational process characteristics and employer requirements.

At present, there is no single methodology to determine the characteristics in question, and each educational organization develops its own questionnaires that do not always ensure a proper consideration of employers' requirements. In our opinion, in order to solve this problem, the most rational is the use of a systematic approach that allows to establish the characteristics of the educational process proceeding from the considerations of the most complete consideration of employer requirements for the quality of the educational service.

In order to form a set of employer controlled characteristics of the educational process, its global goal was defined: "The training of highly qualified personnel whose level of competence meets the conditions of work in an innovative organization", the decomposition of this goal was carried out (Table 1).

Table 1 - Classification of the educational process characteristics, controlled by employers, according to the levels of the educational process goal tree 
The Turkish Online Journal of Design, Art and Communication - TOJDAC

ISSN: 2146-5193, March 2018 Special Edition, p. 31-38

\begin{tabular}{|c|c|}
\hline $\begin{array}{l}\text { Decomposition levels of the educational } \\
\text { process global goal }\end{array}$ & $\begin{array}{c}\text { Characteristics of the educational process, controlled by } \\
\text { employers }\end{array}$ \\
\hline $\begin{array}{l}\text { 1st level. General level of theoretical } \\
\text { and practical training of graduates }\end{array}$ & $\begin{array}{l}\text { - the compliance between the general level of knowledge } \\
\text { and skills of university graduates with modern } \\
\text { requirements of the innovative economy; } \\
\text { - the general level of graduate competence; } \\
\text { - the availability of knowledge and skills necessary to } \\
\text { perform work in accordance with the received } \\
\text { qualifications. }\end{array}$ \\
\hline 2nd level. Types of professional activity & $\begin{array}{l}\text { - the list and the degree of importance concerning the } \\
\text { types of activities necessary for official duty performance; } \\
\text { - the level of competence during the performance of } \\
\text { various activities. }\end{array}$ \\
\hline 3rd level. Competencies & $\begin{array}{l}\text { - the list and the degree of competence importance } \\
\text { necessary to solve the tasks during the performance of } \\
\text { certain types of activities; } \\
\text { - the level of competencies necessary to solve the tasks } \\
\text { during the performance of certain types of activities. }\end{array}$ \\
\hline 4th level. Disciplines & $\begin{array}{l}\text { - the list and the degree of importance concerning the } \\
\text { disciplines necessary for the development of individual } \\
\text { competences. }\end{array}$ \\
\hline $\begin{array}{l}\text { 5th level. Resource support of the } \\
\text { educational process }\end{array}$ & $\begin{array}{l}\text { - the amount of hours devoted to the study of disciplines } \\
\text { and the passage of practices; } \\
\text { - the quality of material and technical support for the } \\
\text { educational process; } \\
\text { - the quality of information support for the educational } \\
\text { process; } \\
\text { - teaching staff quality. }\end{array}$ \\
\hline
\end{tabular}

The presented characteristics of the educational process serve as the basis for the development of a questionnaire for employers. It should be designed in such a way that respondents can express their opinion about the degree of educational process characteristics conformity with their requirements.

The analysis of marketing information obtained in the process of employer interviewing allows us to assess the level of educational service quality, which is the difference between the desired and actually perceived results by the employers concerning educational service provision. In order to determine it, it is expedient to use the methodology of GAP-analysis, developed by American researchers A. Parashuraman, V.A. Zaitaml and L.L. Berry [15].

In accordance with this model, the quality of the educational service from the point of view of consumers depends on the level of inconsistencies between his views about this service and his perception after receiving. The service is of high quality, if there are no discrepancies. 
In the process of GAP-analysis, we identified and structured the following groups of educational process characteristic inconsistencies with the requirements of employers by levels (Table 2).

\section{Table 2 - The distribution of educational process characteristic inconsistencies with the requirements} of employers

\begin{tabular}{|c|c|}
\hline The levels of inconsistencies & Inconsistencies \\
\hline $\begin{array}{l}1 \text { st level. Inconsistencies that involve } \\
\text { weaknesses in the implementation of } \\
\text { the educational program as a whole }\end{array}$ & $\begin{array}{l}\text { discrepancies between the graduate's received training and } \\
\text { innovative economy requirements; } \\
\text { the inconsistencies between the level of theoretical preparation } \\
\text { and employers' requirements } \\
\text { the inability to use the knowledge gained during practical } \\
\text { problem solution. }\end{array}$ \\
\hline $\begin{array}{l}\text { 2nd level. Nonconformities by } \\
\text { professional activity types }\end{array}$ & $\begin{array}{l}\text { inconsistency between the level of theoretical and practical } \\
\text { training concerning the necessary professional activities to } \\
\text { work in this organization. }\end{array}$ \\
\hline $\begin{array}{l}\text { 3rd level. Inconsistencies in the } \\
\text { theoretical and practical training of } \\
\text { students arising in the educational } \\
\text { process during the formation of } \\
\text { competencies required for the } \\
\text { implementation of certain activities }\end{array}$ & $\begin{array}{l}\text { inconsistencies between the level of theoretical and practical } \\
\text { training during the development of competencies necessary for } \\
\text { the implementation of certain types of activities during the } \\
\text { performance of official duties. }\end{array}$ \\
\hline $\begin{array}{l}\text { 4th level. Inconsistencies in the } \\
\text { structure of disciplines, the study of } \\
\text { which is provided by the educational } \\
\text { program and which promotes the } \\
\text { development of specific } \\
\text { competences }\end{array}$ & $\begin{array}{l}\text { inconsistencies between the level of theoretical and practical } \\
\text { training concerning the disciplines necessary for the } \\
\text { development of individual competences. }\end{array}$ \\
\hline $\begin{array}{l}\text { 5th level. Inconsistencies in } \\
\text { curriculum discipline provision with } \\
\text { material, financial, time, labor and } \\
\text { information resources }\end{array}$ & $\begin{array}{l}\text { 1) the discrepancy between the amount of theoretical and } \\
\text { practical work provided in the curriculum for individual } \\
\text { disciplines; } \\
\text { 2) the discrepancy in the amount of practical creative work } \\
\text { provided in the curriculum for individual disciplines; } \\
\text { 3) the discrepancy in the amount of independent work provided } \\
\text { in the curriculum for individual disciplines; } \\
\text { 4) the discrepancy between the quality level of knowledge } \\
\text { control and student skills; } \\
\text { 5) the discrepancy between the quality level of lecture and } \\
\text { practical material teaching; } \\
\text { 6) the discrepancy in the level of use of modern technical } \\
\text { means to present lecture and practical material; }\end{array}$ \\
\hline
\end{tabular}




\begin{tabular}{|l|l|}
\hline The levels of inconsistencies & \multicolumn{1}{|c|}{ Inconsistencies } \\
\hline & $\begin{array}{l}\text { 7) the discrepancy in the level of educational and } \\
\text { methodological support for theoretical and practical training; } \\
\text { 8) the discrepancy in the level of information support for } \\
\text { theoretical and practical training. }\end{array}$ \\
\hline
\end{tabular}

In order to eliminate the revealed discrepancies between the characteristics of educational services that are desired and actually perceived by consumers, it is necessary to study the reasons of their occurrence.

So, the reasons for the inconsistencies of the first level can be low-quality training of personnel on one, several or all types of professional activity.

When you determine the reasons for the inconsistencies of the second level, it is necessary to consider the availability in the curriculum of educational disciplines that form the competence of students and are necessary for the performance of certain types of professional activity.

The reasons for the inconsistencies of the third level are as the preparation of students for disciplines, the study of which allows them to form certain competencies.

At the fourth level, the reasons for the inconsistencies are explained by an insufficient level of resource support for educational program disciplines.

The inconsistencies of the fifth level consist in an ineffective provision of curriculum disciplines with material, financial, time, labor and information resources.

The analysis of discrepancy reasons between the educational service results that are desired and actually perceived by employers constitutes the basis for management decisions to adjust an educational program in order to meet the requirements of employers for the educational process better.

\section{STUDY RESULTS}

The analysis of marketing information on the quality of educational services allows you to determine the level of employer satisfaction. Customer satisfaction is an integral indicator that presupposes the presence of private indicators reflecting the hierarchy of the educational process goals:

1) the indicators of customer satisfaction assessment, characterized by the level of a graduate vocational training as a whole (the level of graduate vocational training, ensuring an effective performance of official duties, the number of contracts with hiring organizations, the proportion of managers satisfied with the level of subordinate graduate professional training, ensuring an effective performance of official duties);

2) the indicators of customer satisfaction assessment, characterized by the level of graduate training according to professional activity type (the level of vocational training of graduates to the implementation of various activities provided by a job description, the proportion of managers satisfied with the level of vocational training of university subordinate graduates to implement various activities provided by a job description);

3) the indicators of customer satisfaction assessment, characterized by the level of a graduate's mastery concerning certain competences (the level of graduate competence required for the implementation of certain types of activities provided by a job description; the proportion of managers satisfied with the level of university subordinate graduate competence during the performance of certain types of activities provided by a job description); 
4) the indicators of the resource availability of disciplines (the proportion of teachers from among the current leaders and the employees of profile organizations, the proportion of students participating in scientific research on employer topics, etc.).

The calculation of the integral indicator of employers' satisfaction allows to assess the level of educational service quality, to assess the correspondence degree between the vocational training of university graduates and employer's requirements.

The implementation of data collection and marketing information analysis mechanism about the quality of educational services proposed in the work also provides educational organizations with significant opportunities concerning the quality of educational services required by employers:

- the achievement of structure compliance and the content of the educational program with the employer's requirements;

- the development of a scientifically grounded list of disciplines, competencies and the types of professional activity, taking into account the degree of their importance for personnel training in accordance with the requirements of a particular employer;

- the planning of methodical, material and technical support for the educational process, taking into account the assessment of resource availability levels concerning individual disciplines and the degree of these disciplines influence on the development of specific competences among students;

- a regular conduct of marketing research to identify inconsistencies between the characteristics of the educational process and the employers' requirements;

- the analysis of the reasons for identified non-conformities and the development of measures for their elimination.

\section{SUMMARY}

In the conditions of innovative economy, universities play a key role in the provision of the real sector of economy and business in general with highly qualified personnel. At the same time, the priority task of educational organizations is to ensure the quality of educational services required by employers [17]. The most important tool improving the quality of these services is marketing research.

The activity ensuring the quality of educational services required by employers on the basis of marketing research implies, first of all, the development of marketing research concept, the collection and the analysis of marketing information [18]. In the process of employer satisfaction study with the quality of educational services, the attention should be paid to the development of questionnaires for the survey, which involves the definition and the decomposition of the educational process global goal, the development of a set of its characteristics, estimated by employers.

In order to analyze the marketing information received from employers about the quality of educational services, it is necessary to use the methodology based on the integrated use of system analysis and GAP analysis methods concerning the revealed discrepancies between the characteristics of the educational process and employers' requirements. The inconsistencies identified in this way should be classified into the levels in the form of a tree of inconsistencies, which makes it possible to identify and analyze the reasons of these discrepancies more clearly.

The proposed mechanism of marketing information analysis about the quality of educational services allows not only to assess the level of highly qualified personnel training quality, but to ensure the high quality of educational services as the result of inconsistency elimination between the characteristics of the educational process and employers' requirements. 


\section{CONFLICT OF INTERESTS}

The authors confirm that the presented data do not contain a conflict of interest.

\section{ACKNOWLEDGMENTS}

The work was prepared with the support of the Ural State Agrarian University (FSBEI HE).

\section{REFERENCES}

Donnik I.M., Voronin B.A., Voronina Ya.V., Kruglov V.V. Organizational and legal and economic mechanisms of natural resources rational use and environmental protection in agriculture // Agrarian Journal of the Urals, 2017. № 08 (162). pp. 10-17.

Golubkov E.P. Basics of marketing: A Textbook. 3rd ed., revised-Moscow: "Finpress" Press, 2008. 704 p.

Griffith Stafford A. A Proposed Model For Assessing Quality Of Education [electronic resource] / International Review of Education, 2008. Vol. 54. Issue 1. pp. 99-112.

Guskova M.V., Zvonnikov V.I. Interaction of employers and universities: yesterday, today, tomorrow // Bulletin of Kostroma State University named after N.A. Nekrasov, 2012. V. 18. No. 6. pp. 48 - 52.

Johnson F. Craig, Golomskiis William A.J. Quality concepts in education / The TQM Magazine, 2000, Vol. 11 Iss: 6, pp. $467-473$.

Kononenko T.E., Bondarenko O.V. The features of educational service market and the problem of university interaction with employers // Modern high technology, 2014. № 7. pp. 53 - 55.

Lysenko, N. N. Analysis of enterprises-employers and university interaction organization // Vocational education in Russia and abroad. 2015. № 3 (19). pp. 125 - 129.

Murav'eva A.A., Aksenova N.M. Interaction of the higher school with the subjects of labor sphere challenges and mutual benefits // MSRU bulletin. (Series: Pedagogy), 2014. No 4. pp. 8 - 15.

N.A. Selezneva. The quality of higher education as an object of system research: Lecture-report. 2nd edition, add. - M.: Expert training quality problem research center, 2002. 95 p.

Nabokov V.I., Gritsova O.A. Marketing research as the tool of high school educational service quality estimation // Economy and business, 2014. № 9. pp. 551-554.

Parasuraman A. The SERVQAL model, at: http://www.arl.org/libqual/events/ oct2000msq/slides/parasuraman/sl001.

Potashnik M. Management of education quality in questions and answers // People education, 2001. № 8. pp. 39-48.

Pustuev A.L., Nabokov V.I., Gorbunova O.S., Petryakova S.V., Kalitskaya V.V., Perminova I.M. Foreign models of human capital development in the agrarian sphere and their use // Agrarian Bulletin of the Urals, 2017. №04 (158). pp. 92-96.

Quality in Higher Education / David Andrew Turner in Comparative and International Education: A Diversity of Voices. 2011, p. 110.

Saburova M.M. To the issue of university and employer interaction at the present stage of Russian society development // Electronic learning in continuous education, 2015. Vol. 1. No. 1 (2). pp. 645-649.

Shevchenko D.A., Kaplan D.A., Kunevich Y.Yu. Modern organization of interaction between a university and employers // Human capital and professional education, 2012. No1 (1). pp. 13 - 17.

Shevelev N.N. Strategic partnership of a university and enterprises - the basis of innovative economic development // Higher education in Russia, 2013. No3. pp. 50 - 54.

The strategy of Russian Federation innovative development for the period up to 2020: approved by the decree of Russian Federation Government on December 8, 2011, No. 2227-p. - M., 2011. 